\title{
Electrodeposition of Hard Golds
}

\author{
A HYPOTHESIS TO EXPLAIN ITS SPECIAL FEATURES
}

\begin{abstract}
Although Munier's discovery (1) of the occurrence of non-metallic impurities in gold electrodeposits from acid cyanide electrolytes containing nickel and cobalt has been followed by numerous studies of various aspects of this phenomenon ( 2 to 14$)$, a full understanding of this and other special features of hard gold deposition remains elusive. Special interest therefore attaches to a hypothesis recently put forward in this connection by E. T. Eisenmann of Bell Laboratories, Columbus, Ohio (15).

The hypothesis is based upon the following picture of cathodic processes occurring in the $\mathrm{Au} / \mathrm{Au}(\mathrm{CN})_{2}$ system as revealed by electrode kinetics studies (16):

Pre-chemical adsorption equilibrium
\end{abstract}

$$
\mathrm{Au}(\mathrm{CN})_{2}^{-} \rightleftharpoons(\mathrm{AuCN}) \mathrm{ad}+\mathrm{CN}^{-}
$$

Electron transfer step (rate limiting)

$$
(\mathrm{AuCN}) \mathrm{ad}+\mathrm{e} \rightleftharpoons\left(\mathrm{Au}^{0} \mathrm{CN}\right)^{-} \mathrm{ad}
$$

Post-chemical desorption and crystallisation

$$
\left(\mathrm{Au}^{\circ} \mathrm{CN}\right)^{-} \mathrm{ad} \rightleftharpoons \mathrm{Au}(\text { lattice })+\mathrm{CN}^{-}
$$

Whereas in soft gold deposition, adsorbed gold cyanide forms a monolayer of a thickness of the order of the Helmholtz double layer, in the presence of a hardener such as cobalt, cobalt ions are postulated as providing a bond between multiple layers of adsorbed $\mathrm{Au}(\mathrm{CN})_{2}$ ions. Polarisation data indicate that processes (1) and (3) are at equilibrium so they are unaffected by the presence of cobalt or nickel. The changes in the double layer structure do, however, affect the energetics of the deposition process. Gold partial current density-potential curves for soft gold and hard gold baths reflect this, indicating a greater irreversibility of the gold-cobalt system.

In the deposition process, the transfer of an electron into the gold-cobalt cyanide complex initiates rearrangements in the adsorbed layer. Moreover, because of the stability of the Au-Co configuration, the transfer of numbers of electrons into the complex is seen as causing localised increases in the concentrations of the reduced species, which nucleate new growth centres and so give rise to the small grain size and hardness which characterise the deposits.

Eisenmann links this mechanism to the properties of three compounds of this type, which he has isolated and studied for the first time, namely
$\mathrm{KCo}\left[\mathrm{Au}(\mathrm{CN})_{2}\right]_{3}, \quad \mathrm{Co}\left[\mathrm{Au}(\mathrm{CN})_{2}\right]_{2} \cdot 10 \mathrm{H}_{2} \mathrm{O}$ and $\mathrm{Co}\left[\mathrm{Au}(\mathrm{CN})_{2}\right]_{2} .4 \mathrm{H}_{2} \mathrm{O}$. He describes evidence which supports the view that these compounds can host within their structures gold metal produced as a result of electron transfer.

It may be conjectured that the reverse is also true, namely that the gold lattice can host compounds of these types and that they are the source of impurities in electrodeposited hard golds. Analyses of hard gold deposits from an Orosene 999 bath (Technic Inc.) have been in accord with the incorporation in them of 2 per cent by weight of $\mathrm{KCo}\left[\mathrm{Au}(\mathrm{CN})_{2}\right]_{3}$.

Even though this latter finding is not in agreement with the results of Knödler (8), it does explain a number of other features of hard gold deposits. The fact that hard gold electrolytes yield dull deposits if the $\mathrm{pH}$ is too high, for example, is explained by the fact that $\mathrm{KCo}\left[\mathrm{Au}(\mathrm{CN})_{2}\right]_{3}$ cannot be precipitated at high $\mathrm{pH}$ values. The formation of dull deposits at high temperatures is also explicable in terms of the thermal dissociation of this complex. Moreover, the tendency of hard gold deposits to blister above $400^{\circ} \mathrm{C}$ corresponds to the observed decomposition of these complexes at this temperature.

Already it seems clear that gold-cobalt complexes, comparable with the various insoluble ferro- and ferri-cyanide complexes such as $\mathrm{KFe}\left[\mathrm{Fe}(\mathrm{CN})_{6}\right]$, $\mathrm{K}_{2} \mathrm{Fe}\left[\mathrm{Fe}(\mathrm{CN})_{6}\right]$ and $\mathrm{Fe}\left[\mathrm{Fe}(\mathrm{CN})_{6}\right]$ must play an important role in the deposition process. Thus in 1965 Raub and Knödler (17) examined pink precipitates which formed mainly in the anodic (or low $\mathrm{pH}$ ) regions of gold-cobalt plating baths and concluded that they were mixtures of $\mathrm{Co}\left[\mathrm{Au}(\mathrm{CN})_{2}\right]_{2}$ and $\mathrm{KCo}\left[\mathrm{Au}(\mathrm{CN})_{2}\right]_{3}$. These investigators have also suggested (7) that cobalt may be incorporated in the electrodeposits as a complex hydride $\mathrm{Co}(\mathrm{CN})_{5} \mathrm{H}^{3+}$, and have pointed out that this accounts for the high hydrogen as well as the carbon and nitrogen contents of the deposits which they have observed, and also their potassium contents as reported by other workers (14). They have also recently observed (17) that when gold-iron electrodeposits prepared under special conditions are dissolved, a blue precipitate is formed which is almost certainly some form of Prussian or Turnbull's Blue.

It is difficult to establish by analytical means, however, the exact form in which such complexes may be incorporated. In the case of gold-cobalt deposits, for example, cobalt may be present in solidsolution as well as in complex form. 
Whether multi-electron transfer to an adsorbed gold-cobalt cyanide complex as proposed by Eisenmann plays a role in the process, or whether the facts can equally well be explained by a simple precipitation-adsorption model remains to be seen. Whatever the outcome, Eisenmann's findings and his ideas should stimulate further attempts to achieve that full understanding of the fundamental processes involved in the formation of these widely used coatings, which is desirable as a basis for attempts to improve their production and their properties.

W. S. R.

\section{References}

1 G. B. Munier, Plating, 1969, 56, 1151

2 L. Holt and J. Stanyer, Trans. Inst. Met: Finish., 1972, 50, 24
3 E. Raub, C. J. Raub, A. Knödler and H. P. Wiehl, Werkst. $u$ Korros., 1972, 23, 643

4 L. Holt, R. J. Ellis and J. Stanyer, Plating, 1973, 60, 910

5 L. Holt, R. J. Ellis and J. Stanyer, Plating, 1973, 60, 918

6 H. A. Reinheimer, f. Electrochem. Soc., 1974, 121, 490

7 C. J. Raub, A. Knöđler and J. Lendvay, Plating Surf. Finish, $1976,68,35$

8 A. Knödler, Metalloberfläche, 1974, 28, 465

9 C. K. Kim and M. J. Vasile, Anal. Chim. Acta, 1971 56, 339

10 M. J. Vasile and D. L. Malm, Anal. Chem., 1972, 44, 650

11 M. Antler, Plating, 1973, 60, 468

12 A. F. Mohrnheim, f. Electrochem. Soc., 1970, 117, 833

13 R. L. Cohen, K. W. West and M. Antler, F. Electrochem. Soc, $1977,124,342$

14 T. A. Davies and P. Watson, Plating, 1973, 63, 1138-1145

15 E. T. Eisenmann, $\not$. Electrochem. Soc., 1977, 124, 1957-1958

16 E. T. Eisenmann, f. Electrochem. Soc., 1978, 125, 717-723, cf. J. A. Harrison and J. Thompson, Electrochim. Acta, 1973, 18, 829-834

17 C. J. Raub and A. Knödler, private communication 